\title{
PIK3R2 Gene
}

National Cancer Institute

\section{Source}

National Cancer Institute. PIK3R2 Gene. NCI Thesaurus. Code C101283.

This gene is involved in the regulation of receptor tyrosine kinase activity. 